Original Research Paper

\title{
Biosynthesis of Zinc Oxide Nanoparticles and Assay of Antibacterial Activity
}

\author{
${ }^{1}$ Emad J. Ibrahem, ${ }^{2}$ Karkaz M. Thalij, ${ }^{2}$ Mahmood K. Saleh and ${ }^{2}$ Amin S. Badawy \\ ${ }^{1}$ Sulaimani Directorate of Health, Ministry of Health Kurdistan, Iraq \\ ${ }^{2}$ Department Food Science, College of Agriculture, Tikrit University, Iraq
}

\author{
Article history \\ Received: 15-09-2015 \\ Revised: 07-12-2016 \\ Accepted: 29-3-2017 \\ Corresponding Author: \\ Karkaz M. Thalij \\ Department Food Science, \\ College of Agriculture, Tikrit \\ University, Iraq \\ Email: kthalij@gmail.com
}

\begin{abstract}
In this study Out of 280 urinary tract infections samples, 212(75.7\%) bacterial isolates were recovered. Based on, morphological, cultural and biochemical testes, further, confirmed the results by VITEK 2 System there were 54 (30.2\%) of gram positive whereas the 158 (69.8\%) of gram negative. The bacterial isolates were distributed as Escherichia coli followed by Klebsiella pneumoniae, Staphylococcus aureus, Pseudomonas aeruginosa and Staphylococcus epidermidis which represented 96(45.2\%), $48(22.6 \%), 43(20.3 \%), 14(6.6 \%)$ and $11(5.2 \%)$ respectively. The synthesis of Zinc Oxide nanoparticles (ZnO NPs) using biological methods as eco-friendly from the use of Aspergillus niger filtrate in the extracellular synthesis, then identified and characterized by UV-Vis Spectrophotometer and Scanning Electron Microscopy (SEM). Furthermore, determine the antibacterial efficacy of biological synthesized ZnO NPs against isolated pathogens microbes Staphylococcus aureus and Escherichia coli. The results found the used of $100 \mathrm{~mL}$ of ZnCL2 in cultivation of Aspergillus niger was obtained and biosynthesis of ZnO NPs at $46 \mathrm{mg}$. SEM was illustrate the morphology and practices of ZnO NPs sizes and appear as spherical in shape besides, the size range at $41-75 \mathrm{~nm}$. The assurance by the UV-Vis spectrum appears the absorption bands of ZnO NPs at $380 \mathrm{~nm}$. The results of 1.0 and $1.5 \mathrm{mg} \mathrm{mL}^{-1}$ from $\mathrm{ZnO}$ NPs synthesized from A. niger were effect of inhibition against $S$. aureus and E. coli bacterial isolated from urine tracts infection sources. The Inhibition Zone Diameters (IZD) against $S$. aureus was appear at 24 and $26 \mathrm{~mm}$ respectively compared with the IZD from Ciprofloxacin alone at $20 \mathrm{~mm}$. while the same concentration from ZnO NPs against $E$. coli causing in IZD at 25 and $28 \mathrm{~mm}$ respectively compared with Ciprofloxacin inhibition alone at $23 \mathrm{~mm}$.
\end{abstract}

\section{Keywords: Zinc Oxide NPs, Aspergillus niger, SEM, Antibacterial Activity}

\section{Introduction}

Nano biotechnology has now emerged as integration between nanotechnology and biotechnology for developing biosynthetic and eco-friendly technology for synthesis of nanomaterials (Rai et al., 2009). Applying nanotechnology has occurred rapidly and the use of nanoparticle is being used in all sciences in area of chemistry, physics, medicine and biology (Ozin et al., 2009). Nanoparticles usually ranging in dimension from $1-100 \mathrm{~nm}$ the decrease in the dimensions of the materials to the atomic level, was caused to change in their properties (Gutierrez et al., 2010).

Nanoparticles can be synthesized by physical, chemical and biological methods (Kathiresan et al.,
2009). Synthesis of nanoparticles employing microorganisms has attracted much due to their usual optical, chemical, photoelectron chemical and electronic properties and many biological organisms, such as bacteria, fungus, yeasts and plants either intra or extracellular (Castro-Longoria et al., 2010). The biological method of the $\mathrm{ZnO}$ NPs synthesis is gaining importance due to its simplicity, eco-friendliness and extensive antimicrobial activity (Gunalan et al., 2012).

The main factor for the increase of the resistance pathogenic bacteria is overuse of antibiotics and this has led to the emergence and spread of resistant pathogens and resistant genes in them (Van den Bogaard and Stobberingh, 2000). Nanoparticles as antimicrobial agents are their better efficiency on resistant bacteria, less toxicity and 
heat resistance. Among metal oxide Nanoparticles, $\mathrm{ZnO}$ have many significant features such as chemical and physical stability, high catalysis and effective antibacterial activity (Kalyani et al., 2006). The inorganic materials kill bacteria through various mechanisms, such as by binding to intracellular proteins and inactivating them, generation of reactive oxygen species and via directs damage to cell walls (Gao and Cranston, 2008). Lakshmi et al., (2012) studied the antibacterial activity of $\mathrm{ZnO}$ NPs, namely, clinical isolates: Bacillus subtilis, Escherichia coli, Klebsiella pneumoniae, Pseudomonas aeruginosa, Salmonella typhi and Staphylococcus aureus.

In this study, $\mathrm{ZnO}$ NPs were synthesized using biological synthesis mediated from fungi, characterization and also evaluation of their antimicrobial activity against of Staph. aureus and E. coli isolated from UTI samples using disk diffusion and well diffusion assay.

\section{Materials and Methods}

\section{Samples Collections}

Urine samples of patients were collected from Microbial Laboratory in Emergency Hospitals, Sulimaini, Iraq. They were treatments to isolation and identification of pathogenic bacterial isolates according to the standard methods which recommended by (McFaddin, 2000; Steve et al., 2004). Confirmed by VITEK 2 System (Version 5.01 BioMerieux).

\section{Synthesis of ZnO Nanoparticles}

The $\mathrm{ZnO}$ nanoparticles were prepared by using some modification in the method of Jacob et al. (2014). The Aspergillus niger ATCC 16404 was cultivation in Potato Dextrose broth (Difco, USA) used $250 \mathrm{~mL}$ Erlenmeyer flask with agitating by orbital shaker (Mimmert, UK) at $150 \mathrm{rpm}, 28^{\circ} \mathrm{C}$ for $72 \mathrm{~h}$. Fungal supernant was obtained by passing through Whatman No.1. then $10 \mathrm{~mL}$ of supernatant was mixed with $100 \mathrm{~mL}$ of $0.25 \mathrm{mM}$ solution of $\mathrm{ZnCl} 2$ (Sigma Aldrich, Germany), in 250 $\mathrm{mL}$ Erlenmeyer flask and cultivation at $28^{\circ} \mathrm{C}$ with agitation at $150 \mathrm{rpm}$ for $96 \mathrm{~h}$. ZnO NPs was obtained throw the fungal mycelium centrifuge at $3000 \mathrm{rpm}$ for 15 mint., then the participation was drying in oven at $60^{\circ} \mathrm{C}$ and harvested the ZnO NPs and weighted.

Characterization of $\mathrm{ZnO}$ NPs was describing using scanning electron microscope (Cam Scan 3200 LV; England) and record the micrograph images of $\mathrm{ZnO}$ NPs synthesized. Sample was fixated by glutaraldehyde, dehydrated by alcohol for SEM analysis (Vigneshwaran et al., 2007; Talebia et al., 2010). For assurance the ZnO NPs characterization also used the UV-Vis Spectrophotometer spectrum technique to measure the structural characterization of nanoparticles by determine the absorbance measurement (Haiss et al., 2007).

\section{Preparation of Microbial Suspensions}

Antimicrobial activities of $\mathrm{ZnO}$ NPs were conducted against pathogenic bacteria isolates. Gram positive bacteria $S$. aureus and Gram negative E. coli. Agar well diffusion were used in this study. A suspension of bacterial isolates was freshly prepared by inoculating stock culture from each isolates into $3 \mathrm{~mL}$ of Mueller Hinton Broth (Difco, USA) separate broth tubes. The inoculated tubes were incubated at $37^{\circ} \mathrm{C}$ for $24 \mathrm{~h}$. Bacterial accounts assay used 0.5 concentrations tube from McFarland technique for screening of antimicrobial activities.

\section{Antimicrobial Activity}

The technique was performed using agar well diffusion (Magaldi et al., 2004) the suspension bacterial cultivation for $24 \mathrm{~h}$ from each isolates of $E$. coli and $S$. aureus adjusted to 0.5 McFarland turbidity standard described by Padmavathy and Vijayaraghavan (2008). About $100 \mu \mathrm{L}$ of each bacterial suspension was spreading by swabs onto surface of Mueller-Hinton agar plates and were left (10-15 min) until the surface of agar has dried. Then the wells were made into agar at $4 \mathrm{~mm}$ diameter using cork borer with the distance between well and another more than $22 \mathrm{~mm}$. About $50 \mu \mathrm{L}$ from 1.0 and 1.5 of $\mathrm{ZnO}$ NPs and $0.5 \mathrm{mg}$ of Ciprofloxacin (Bioanalyse/Turkey) were injected in each wells. Then the plates were incubated at $37^{\circ} \mathrm{C}$ for $24 \mathrm{~h}$, the diameters of inhibition were recorded in millimeter using metric ruler.

\section{Statistical Analysis}

Data were analyzed by the ANOVA analysis, using the general linear model of the Statically Analysis System (SAS Institute, 2001). Significant treatment differences were evaluated using Duncan's multiplerange test (Duncan, 1955). All statements of significance are based on the 0.5 level of probability.

\section{Results and Discussion}

\section{Isolation and Identification of Bacterial Isolates}

Table 1, shows the isolated microorganisms from urine source, which were identified according to the microscopic, macroscopic and biochemical tests and the results confirmed by VITEK-2 SYSTEM. The most frequently isolated bacteria significantly $(\mathrm{p}<0.05)$ were Escherichia coli 96 (45.2\%) followed by, Klebsiella pneumoniae 48 (22.6\%), Staphylococcus aureus 43(20.3\%), Pseudomonas aeruginosa 14 (6.6\%) and Staphylococcus epidermidis 11 (5.2\%). This result was in agreement with Inbaneson et al. (2011).

The isolates were cultured on Blood, MacConkey and Mannitol Salt agar plates and incubated at $37^{\circ} \mathrm{C}$ for $24 \mathrm{~h}$. They were identified according to colony characteristics and microscopic examination of stained smear that 
demonstrate microbial shape, structure, agreement, gram stain reaction and biochemical tests like indol (I), Methyl Red (M.R), Vogas Proskauer (V.P), citrate utilization, oxidase (C), motility test, catalase, coagulase and urease production; according to Brown (2007) as in Table 2. Then the identification was confirmed by using VITEK 2 compact system as recommended by Biomerieux. Our results were compared with the resource reported by (Collee et al., 1996; McFadden, 2000).

\section{Biosynthesis of ZnO NPs}

The biosynthesis of ZnO NPs was conducted by cultivation of Aspergillus niger on potato dextrose broth media enrichments with $\mathrm{ZnCL} 2$ at $28^{\circ} \mathrm{C}$ with agitation at $150 \mathrm{rpm}$ for $96 \mathrm{~h}$, (Fig. 1a and b). the range of ZnO NPs weight was at $46 \mathrm{mg}$ the ability of Aspergillus niger on synthesis of nanoparticles from ZnCL2 and reduced the particles from micro to Nano size were depended on the enzymes and the metabolic pathways that needed from fungal isolate. The metabolic reactions were obtained with catalytic activity. The Nano-sized $\mathrm{ZnO}$ suspension clearly has a much higher activity than the micron-sized $\mathrm{ZnO}$ suspension (Zhang et al., 2010). However, development of simple and eco-friendly route would help in promoting further interest in the synthesis and application of $\mathrm{Zn}, \mathrm{Mg}$ and $\mathrm{Ti}$ nanoparticles. Previous studies have indicated that NADH and NADH dependent enzymes are important factors in the biosynthesis of metal nanoparticles (Ahmad et al., 2003a; 2003b).

\section{Characterization of $\mathrm{ZnO} N \mathrm{NS}$}

Scanning Electron Microscopy (SEM) performed has provided further insight into the morphology and size details of the synthesized nanoparticles. It is able to detect of their purity and particle size revealed on the formation of mono and poly dispersed nanoparticles and the $\mathrm{ZnO}$ NPs was appeared in the size range of 41 to 75 $\mathrm{nm}$ (Fig. 2). The morphology of the nanoparticles is variable with majority of them being spherical. SEM studies clearly establish that the reduction of $\mathrm{Zn}$ ions occurs extracellular, it would be important to identify the reducing agents responsible for this reaction.

The UV-Vis Spectrophotometer technique were used to measure the structural characterization of nanoparticles by determine the absorbance measurement and the UV-Vis spectrum of ZnO NPs was appear at 380 $\mathrm{nm}$ absorption bands, (Fig. 3). The absorption peak was appearing as similar the absorption band for the results obtained by Mashrai et al. (2013).
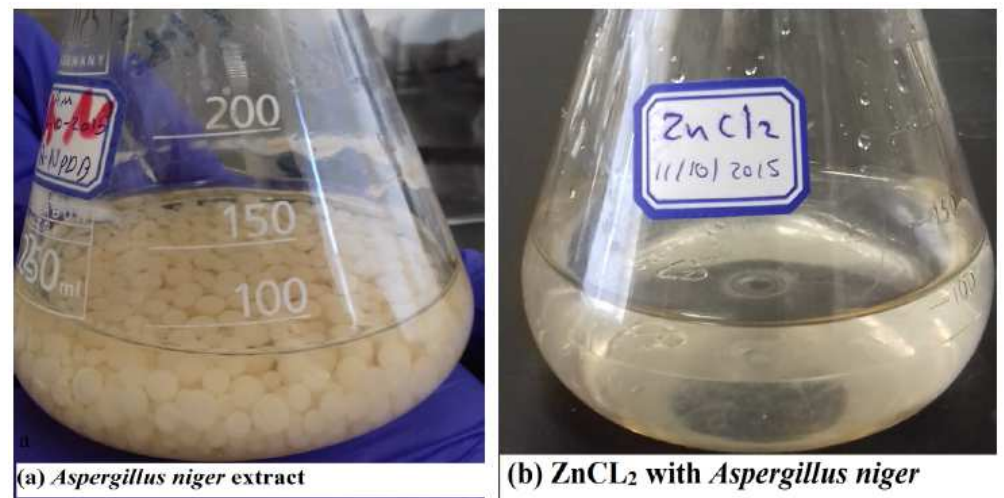

(b) $\mathrm{ZnCL}_{2}$ with Aspergillus niger

Fig. 1. Biosynthesis of $\mathrm{ZnO}$ NPs (a) Aspergillus niger extracts (b) $\mathrm{ZnCL}_{2}$ with Aspergillus niger extract after $72 \mathrm{~h}$ of incubation

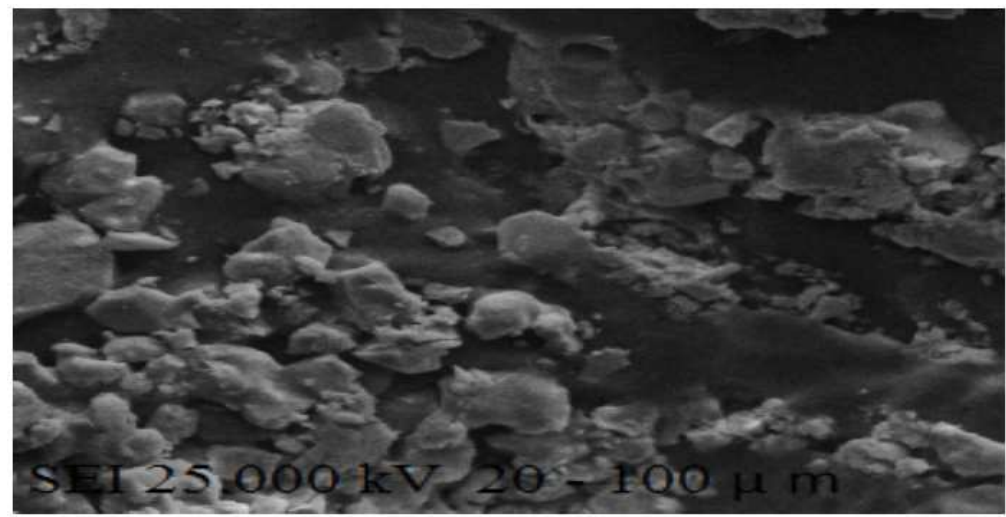

Fig. 2. SEM image of biosynthesized zinc oxide nanoparticles by A. niger 


\section{ZnO NPs Absorbance}

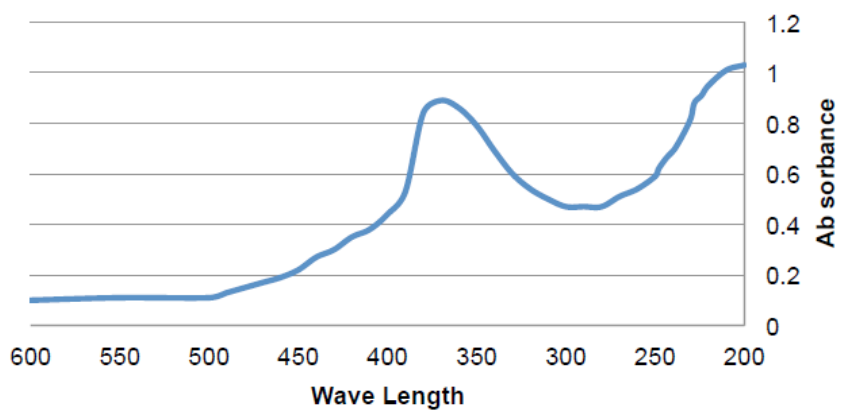

Fig. 3. The UV-Vis spectrum of ZnO nanoparticles synthesized by A. niger
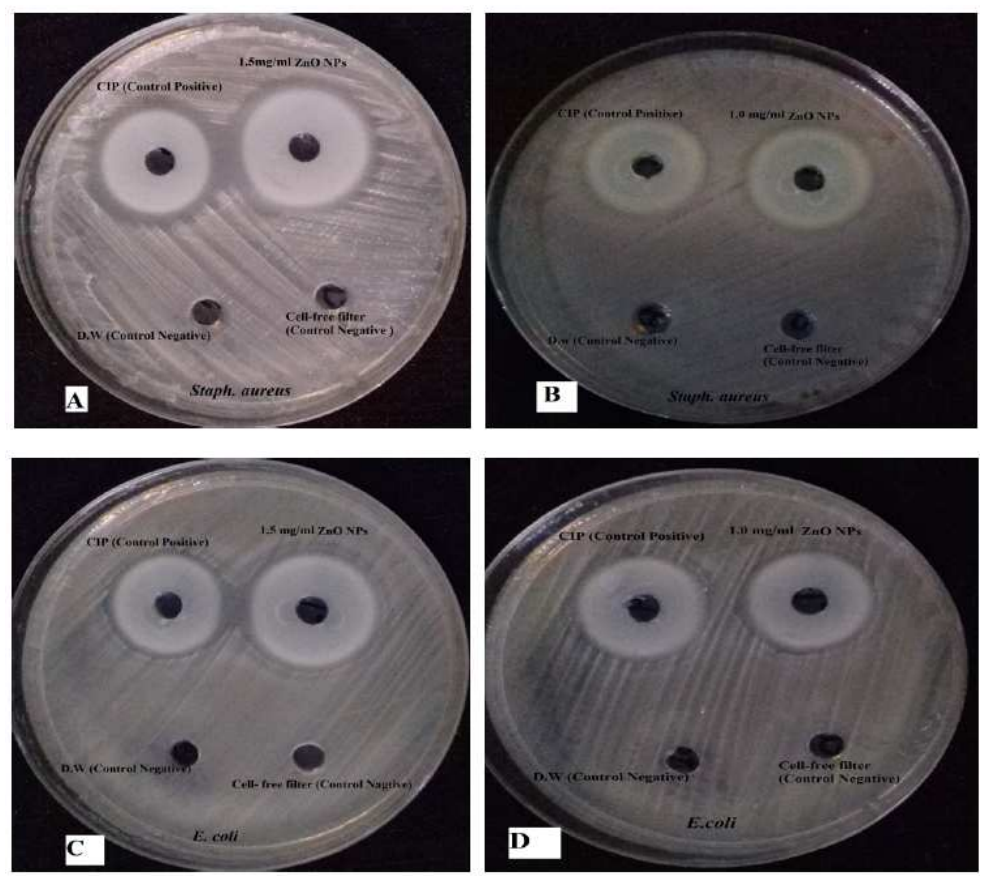

Fig. 4. Antibacterial activity of $\mathrm{ZnO} N$ Ps used well diffusion test (A) at $1.5 \mathrm{mg} \mathrm{mL} \mathrm{m}^{-1}$ against on S. aureus; (B) at $1.0 \mathrm{mg} \mathrm{mL}^{-1}$ against on $S$. aureus; (C) at $1.5 \mathrm{mg} \mathrm{mL}^{-1}$ against E. coli; (D) $1.0 \mathrm{mg} \mathrm{mL}$ ) against E. coli

Table 1. Accounts of isolated bacteria from urine samples

\begin{tabular}{lll}
\hline Bacterial strain & $\begin{array}{l}\text { Accounts of } \\
\text { bacteria isolates }\end{array}$ & $\%$ \\
\hline E.coli & $96 \mathrm{a} \pm 5.48$ & $45.2 \mathrm{a} \pm 4.22$ \\
K.pneumoniae & $48 \mathrm{~b} \pm 4.05$ & $22.6 \mathrm{~b} \pm 2.57$ \\
P. aeruginosa & $14 \mathrm{~d} \pm 1.19$ & $6.6 \mathrm{c} \pm 1.02$ \\
S. Aureus & $43 \mathrm{c} \pm 2.65$ & $20.3 \mathrm{~b} \pm 3.38$ \\
S. epidermidis & $11 \mathrm{e} \pm 1.37$ & $5.2 \mathrm{c} \pm 0.70$ \\
Total & 212 & 100 \\
\hline
\end{tabular}

a-e: Values within columns followed by different letters differ significantly at 0.05

\section{Antibacterial Activities of $\mathrm{ZnO} N P$ s}

Antimicrobial activity of biological synthesized $\mathrm{ZnO}$ NPs of concentrations at 1.0 and $1.5 \mathrm{mg} \mathrm{mL}^{-1}$ against gram positive $S$. aureus and gram negative bacteria $E$. coli were tested by the well diffusion agar methods are represented in the Fig. 4 (A, B, C and D). Table 3 Illustrated the results of 1.0 and $1.5 \mathrm{mg} \mathrm{mL}^{-1} \mathrm{ZnO}$ NPs synthesized from $A$. niger effective antibacterial activity against $S$. aureus and the Inhibition Zone Diameters (IZD) were appear at 24 and 26 $\mathrm{mm}$ respectively compared with the IZD from Ciprofloxacin alone at $20 \mathrm{~mm}$. while the same concentration from ZnO NPs against $E$. coli causing in IZD at 25 and $28 \mathrm{~mm}$ compared with Ciprofloxacin inhibition alone at $23 \mathrm{~mm}$. The results were appeared the effects of $\mathrm{ZnO}$ NPs against gram positive bacteria was significantly more than effects on gram negative bacteria. Also, the results appeared that the inhibitory effect of $\mathrm{ZnO}$ was significantly increased with the increase in concentration. The results for the biologically synthesized $\mathrm{ZnO}$ were comparable to the results obtained for ciprofloxacin $\left(0.5 \mathrm{mg} \mathrm{mL}^{-1}\right)$. 
Table 2. Some biochemical tests used for identification of bacteria Biochemical tests

\begin{tabular}{|c|c|c|c|c|c|c|c|}
\hline \multirow[b]{2}{*}{ Isolated Bacteria } & \multicolumn{7}{|c|}{ 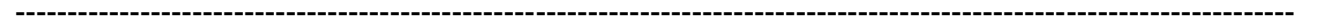 } \\
\hline & Catalase & Coagulase & Oxidase & Indole & M.R & V.P & Citrate \\
\hline$\overline{E . c o l i}$ & $\mathrm{~N}$ & $\mathrm{~N}$ & + & + & + & - & - \\
\hline K. pneumonia & $\mathrm{N}$ & $\mathrm{N}$ & + & - & - & + & + \\
\hline P. aeruginosa & $\mathrm{N}$ & $\mathrm{N}$ & + & - & - & - & + \\
\hline S. aureus & + & + & - & $\mathrm{N}$ & $\mathrm{N}$ & $\mathrm{N}$ & $\mathrm{N}$ \\
\hline S. epidermidis & + & - & - & $\mathrm{N}$ & $\mathrm{N}$ & $\mathrm{N}$ & $\mathrm{N}$ \\
\hline
\end{tabular}

Table 3. Antibacterial activity of ZnO NPs synthesized by A. niger

\begin{tabular}{lllll}
\hline & Zone of inhibition $(\mathrm{mm})$ well diffusion & & \\
& & & \\
Microorganism & Conc. $1.0 \mathrm{mg} \mathrm{mL}^{-1}$ & Conc. $1.5 \mathrm{mg} \mathrm{mL}^{-1}$ & Ciprofloxacin $0.5 \mathrm{mg} \mathrm{mL}^{-1}$ & D.W \\
\hline E. coli & $24 \mathrm{a} \pm 2.47$ & $26 \mathrm{~b} \pm 3.36$ & $20 \mathrm{~b} \pm 1.28$ & $4 \mathrm{a} \pm 0.61$ \\
Staph. aureus & $25 \mathrm{a} \pm 1.81$ & $28 \mathrm{a} \pm 2.75$ & $23 \mathrm{a} \pm 1.60$ & $4 \mathrm{a} \pm 0.55$ \\
\hline
\end{tabular}

a-b: Values within columns followed by different letters differ significantly at 0.05

The presence of an inhibition zone clearly by ZnO NPs in this study were agreement with the previous study by (Rizwan et al., 2010; Emami-Karvani and Chehrazi, 2011) whom have been seen that the increasing of $\mathrm{ZnO}$ NPs concentration causing in increased the inhibition zone diameters for gram negative and positive bacteria. This may be due to the destructive effect of $\mathrm{ZnO}$ NPs with the cells and increased production of active oxygen such as $\mathrm{H}_{2} \mathrm{O}_{2}$, leads to the cell death (Zhang et al., 2010). Furthermore the ZnO NPs, was caused when adherence to the surface of the cell membrane, in disturbance of respiration mechanical through interact with enzymes of the respiration chains of bacteria (Jones et al., 2008). Also from the results were appear that the inhibition zone was affected with the different in the bacterial types and shown the gram positive bacteria were more sensitive for $\mathrm{ZnO}$ NPs compared to the gram negative bacteria (Tam et al., 2008; Tayel et al., 2011) and these were related to differences in cell wall structure, cell physiology and metabolism pathway (Emami-Karvani and Chehrazi, 2011).

\section{Conclusions}

Concluded the ZnO NPs has broad-spectrum activity against bacteria and the inhibition against gram positive were more activity compared with the gram negative bacteria. Also the antibacterial activity was increased with the increased of $\mathrm{ZnO}$ NPs concentration.

\section{Acknowledgement}

Our thanks and appreciation to the Department of Biology, College of Education for pure Sciences, Tikrit University for funding supported.as well as to the laboratory staff in the Faculty of science, Sulaimani University, IRAQ in helping them to provide most the requirements for a successful search.

\section{Author's Contributions}

Karkaz M. Thalij, designed of the experiments and supervision for all the research work, statistical analyses and prepared the manuscript. Emad J. Ibrahem, participated in running all the experiments works besides, the preparing of draft manuscript. Mahmood K. Saleh and Amin S. Badowy, performed the experiments and helped to assisted in certain aspects of the experiments. All authors read and approved the final manuscript.

\section{Ethics}

The authors declare their responsibility for any of the ethical issues that may arise after the publication of this manuscript.

\section{References}

Ahmad, A., P. Mukherjee, S. Senapati, D. Mandal and M.I. Khan et al., 2003a. Extracellular biosynthesis of silver nanoparticles using the fungus Fusarium oxysporum. Coll. Surf. B., 28: 313-318. DOI: $10.1016 / \mathrm{S} 0927-7765(02) 00174-1$

Ahmad, A., S. Senapati, M. Islam Khan, R. Kumar and M. Sastry, 2003b. Extracellular biosynthesis of monodisperse gold nanoparticles by a novel extremophilic actinomycete, Thermomonospora $s p$. Langmuir, 19: 3550-3553. DOI: 10.1021/la0267721

Brown, A.E., 2007. Benson's Microbiological Applications: Laboratory Manual in General Microbiology. Mc Graw Hill, New York.

Castro-Longoria, E., A.R. Vilchis-Nestor and M. Avalos-Borja, 2010. Biosynthesis of silver, gold and bimetallic nanoparticles using the filamentous fungus Neurospora crassa. Colloids Surf. B Biointerfaces, 23: 112-117. PMID: 21087843 
Collee, J.G., A.G. Fraser, B.P. Marmion and A. Simmons, 1996. Mackie and McCartney, Practical Medical Microbiology. 14th Edn., Churchill Livingstone, pp: 41.

Duncan, D.B., 1955. Multiple range and multiple F tests. Biometric, 11: 1-42. DOI: $10.2307 / 3001478$

Emami-Karvani, Z. and P. Chehrazi, 2011. Antibacterial activity of $\mathrm{ZnO}$ nanoparticle on gram-positive and gram-negative bacteria. Afr. J. Microbiol. Res., 5: 1368-1373.

Gao, Y. and R. Cranston, 2008. Recent advances in antimicrobial treatments of textiles. Textile Res. J., 78: $60-72$.

Gunalan, S., R. Sivaraj and V. Rajendran, 2012. Green synthesized $\mathrm{ZnO}$ nanoparticles against bacterial and fungal pathogens. Prog. Nat. Sci. Mater. Int., 22: 693-700. DOI: 10.1016/j.pnsc.2012.11.015

Gutierrez, F.M., P.L. Olive, A. Banuelos, E. Orrantia and N. Nino et al., 2010. Synthesis, characterization and evaluation of antimicrobial and cytotoxic effect of silver and titanium nanoparticles. Nanomedicine, 6: 681-688. DOI: 10.1016/j.nano.2010.02.001

Haiss, W., N.T.K. Thanh, J. Aveyard and D.G. Fernig, 2007. Determination of size and concentration of gold nanoparticles from UV-Vis spectra. Anal. Chem., 79: 4215-23. DOI: 10.1021/ac0702084

Inbaneson, S.J., S. Ravikumar and N. Manikandan, 2011. Antibacterial potential of silver nanoparticles against isolated urinary tract infectious bacterial pathogens. Applied Nanosci., 1: 231-236. DOI: 10.1007/s13204-011-0031-2

Jacob, S.P., R. Bharathkumar and G. Ashwathram, 2014. Aspergillus niger mediated synthesis of $\mathrm{ZnO}$ nanoparticles and their antimicrobial and in vitro anticancerous activity. World J. Pharm. Res, 3: 3044-3054.

Jones, N., B. Ray, K.T. Ranjit and A.C. Manna, 2008. Antibacterial activity of $\mathrm{ZnO}$ nanoparticle suspensions on a broad spectrum of microorganisms. FEMS Microbiol. Lett., 279: 71-76. DOI: 10.1111/j.1574-6968.2007.01012.x

Kalyani, G., V.G. Anil, C. Bo-Jung and L. Yong-Chien, 2006. Preparation and characterization of $\mathrm{ZnO}$ nanoparticles coated paper and its antibacterial activity study. J. Green Chem., 8: 1034-1041. DOI: $10.1039 / \mathrm{B} 605623 \mathrm{G}$

Kathiresan, K., S. Manivannan, M.A. Nabeel and B. Dhivya, 2009. Studies on silver nanoparticles synthesized by a marine fungus, Penicillium fellutanum isolated from coastal mangrove sediment. Colloids Surf. B Biointerfaces, 71: 133-137. DOI: 10.1016/j.colsurfb.2009.01.016

Lakshmi, P.B., M. Mahesh and J. Deepthi, 2012. Development and validation of nabumtone by isocratic RP-HPLC method. Int. Res. J. Pharm. Applied Sci., 2: 92-98.
McFadden, J.F., 2000. Biochemical Tests for Identification of Medical Bacteria. 3rd Edn., Lippincott Williams and Wilkins, Philadelphia, pp: 912.

Magaldi, S., S. Mata-Essayag, C.H. De Capriles, C. Perez and M.T. Colella et al., 2004. Well diffusion for antifungal susceptibility testing. Int. J. Infect. Dis., 8: 39-45. DOI: 10.1016/j.ijid.2003.03.002

Mashrai, A., H. Khanam and R.N. Aljawfi, 2013. Biological synthesis of $\mathrm{ZnO}$ nanoparticles using $C$. albicans and studying their catalytic performance in the synthesis of steroidal pyrazolines. Arabian J. Chem. DOI: 10.1016/j.arabjc.2013.05.004

McFaddin, J.F., 2000. Biochemical Tests for Identification Medical Bacteria. 3rd Edn., Lippincott Williams and Wilkins.

Ozin, G.A., A.C. Arsenault and L. Cademartiri, 2009. Nanochemistry: A Chemical Approach to Nanomaterials. 1st Edn., Royal Society of Chemistry, Cambridge, ISBN-10: 184755895X, pp: 820.

Padmavathy, N. and R. Vijayaraghavan, 2008. Enhanced bioactivity of $\mathrm{ZnO}$ nanoparticles - an antimicrobial study. Sci. Technol. Adv. Mater., 9: 35-40. DOI: 10.1088/1468-6996/9/3/035004

Rai, M., A. Yadav and A. Gade, 2009. Silver nanoparticles as a new generation of antimicrobials. Biotechnol. Adv., 27: 76-83. DOI: 10.1016/j.biotechadv.2008.09.002

Rizwan, W., K. Young-Soon, M. Amrita, Y. Soon-Il and S.H. Hyung-Shik, 2010. Formation of $\mathrm{ZnO}$ micro-flowers prepared via solution process and their antibacterial activity. J. Nanoscale Res. Lett., 5: 1675-1681. DOI: 10.1007/s1 1671-010-9694-y

SAS Institute, 2001. Statistical Analysis System. SAS Institute Inc.

Steve, K., S. Dennis and J. Mary, 2004. Laboratory exercisesin microorganism and molecular microbiology. ASM. Washigton, USA.

Talebia, S., F. Ramezanib and M. Ramezani, 2010. Biosynthesis of metal nanoparticles by microorganisms. Nonocon, 10: 112-118.

Tam, K.H., A.B. Djurišić, C.M.N. Chan, Y.Y. Xi and C.W. Tse et al., 2008. Antibacterial activity of $\mathrm{ZnO}$ nanorods prepared by a hydrothermal method. Thin Solid Films, 516: 6167-6174. DOI: $10.1016 /$ j.tsf.2007.11.081

Tayel, A.A., W.F. El-Tras, S. Moussa, A.F. El-Baz and H. Mahrous et al., 2011. Antibacterial action of zinc oxide nanoparticles against foodborne pathogens. J. Food Safety, 31: 211-218. DOI: $10.1111 / \mathrm{j} .1745-4565.2010 .00287 . \mathrm{x}$

Van den Bogaard, A.E. and E.E. Stobberingh, 2000. Epidemiology of resistance to antibiotics: Links between animals and humans. Int. J. Antimicrobi. Agents, 14: 327-335. PMID: 10794955 
Vigneshwaran, N., N.M. Ashtaputre, P.V. Varadarajan, R.P. Nachane and K.M. Paralikar et al., 2007. Biological synthesis of silver nanoparticles using the fungus Aspergillus flavus. J. Mater. Lett., 67: 1413-1418.

DOI: $10.1016 /$ j.matlet.2006.07.042
Zhang, L., Y. Jiang, Y. Ding, N. Daskalakis and L. Jeuken et al., 2010. Mechanistic investigation into antibacterial behaviour of suspensions of $\mathrm{ZnO}$ nanoparticles against E. coli. J. Nanoparticle Res., 12: 1625-1636. DOI: 10.1007/s1 1051-009-9711-1 